\title{
Difficulties faced by nurses to use pain as the fifth vital sign and the mechanisms/actions adopted: an integrative review
}

\author{
Dificuldades enfrentadas pela enfermagem na aplicabilidade da dor como quinto sinal vital e os \\ mecanismos/ações adotados: revisão integrativa
}

Allana Fernandes Valério ${ }^{1}$, Karina da Silva Fernandes ${ }^{1}$, Grazielle Miranda², Fábio de Souza Terra ${ }^{1}$

DOI 10.5935/2595-0118.20190013

\section{ABSTRACT}

BACKGROUND AND OBJECTIVES: Pain was recognized as the fifth vital sign in 1996, and many nurses have difficulty in evaluating it. Since it is necessary to know the difficulties to use pain as a fifth vital sign, this study aims at acquiring a better knowledge about pain, assessment methods and strategies/ actions to guarantee its control. The objective of this study was to identify and analyze, in the Brazilian and international literature, the difficulties faced by nurses to use pain as the fifth vital sign and the mechanisms/actions adopted.

CONTENTS: It is an integrative review in which the search for scientific articles was carried out in LILACS, BDENF, Scielo, Pubmed, Scopus and Web of Science databases, using the descriptors nursing, pain, and pain and vital signs management in Portuguese, English, and Spanish. The selection criteria were the period from 1995 to 2017 in the three languages mentioned. After searching and reading the articles, nine studies were included. Two categories were listed after reading the articles: 1) difficulties faced by nurses to use pain as a fifth vital sign and 2) mechanisms/actions adopted to minimize the difficulties faced by nurses to use pain as a fifth vital sign.

CONCLUSION: It was evidenced that it is important that nurses consider/assess pain as the fifth vital sign, therefore aiming at better care, which, consequently, will influence the quality of care provided, improving patient's health and quality of life.

Keywords: Nursing, Pain, Pain management, Vital signs.

\footnotetext{
Allana Fernandes Valério - Dhttps://orcid.org/0000-0002-6748-1385; Karina da Silva Fernandes - (Dhttps://orcid.org/0000-0002-8298-6082;

Grazielle Miranda - Dhttps://orcid.org/0000-0001-6206-7452;

Fábio de Souza Terra - Dhttps://orcid.org/0000-0001-8322-3039.

1. Universidade Federal de Alfenas, Escola de Enfermagem, Alfenas, MG, Brasil.

2. Universidade Federal de Alfenas, Escola de Enfermagem, Mestranda pelo Programa de Pós-Graduação em Enfermagem, Alfenas, MG, Brasil.
}

Submitted in July 10, 2018.

Accepted for publication in December 13, 2018.

Conflict of interests: none - Sponsoring sources: none

Correspondence to:

Rua Gabriel Monteiro da Silva, 700 - Centro

37130-001 Alfenas, MG, Brasil.

E-mail: karina.frnds@hotmail.com

(C) Sociedade Brasileira para o Estudo da Dor

\section{RESUMO}

JUSTIFICATIVA E OBJETIVOS: A dor foi reconhecida como quinto sinal vital em 1996 e muitos enfermeiros têm dificuldades em avaliá-la. Mediante a necessidade de conhecer as dificuldades na aplicabilidade da dor como quinto sinal vital, justifica-se este estudo com o intuito de conhecer a dor, os métodos para avaliação e as estratégias/açóes para garantir seu controle. $\mathrm{O}$ objetivo deste estudo foi identificar e analisar, na literatura brasileira e internacional, as dificuldades enfrentadas pela enfermagem na aplicabilidade da dor como quinto sinal vital e os mecanismos/ açôes adotados.

CONTEÚDO: Trata-se de uma revisão integrativa em que a busca de artigos científicos foi realizada nas bases e bancos de dados: LILACS, BDENF, Scielo, Pubmed, Scopus e Web of Science. Utilizou-se os descritores enfermagem, dor, manuseio da dor e sinais vitais nos idiomas português, inglês e espanhol. Definiu-se como critérios de seleção o período de 1995 a 2017 e os três idiomas citados; e após a busca e a leitura dos artigos foram incluídos nove estudos. Com a leitura dos artigos foram elencadas duas categorias: 1) dificuldades enfrentadas pela enfermagem na aplicabilidade da dor como quinto sinal vital e 2) mecanismos/ açóes adotados para amenizar as dificuldades enfrentadas pela enfermagem na aplicabilidade da dor como quinto sinal vital.

CONCLUSÃO: Evidenciou-se que é necessário que os profissionais enfermeiros atentem para a importância de considerar/ avaliar a dor como quinto sinal vital, visando um melhor atendimento que, consequentemente, influenciará na qualidade da assistência prestada, melhorando a saúde e a qualidade de vida do paciente.

Descritores: Dor, Enfermagem, Manuseio da dor, Sinais vitais.

\section{INTRODUCTION}

Pain was first recognized and cited as the fifth vital sign in 1996 by James Campbell (President of the American Pain Society) ${ }^{1}$. One of Campbell's goals was to raise health professionals' awareness about the beneficial effects of proper pain assessment and early management ${ }^{2}$.

Since the nursing team is close to the patients, as well as other health professionals, such as physicians, it is crucial that the nursing leadership recognizes their responsibility with the individual with pain, so that the nurse can systematize the nursing care and identify the appropriate interventions for pain relief. This may minimize its effects, contribute for better 
evolution of the patient and, consequently, provide an effective treatment to pain ${ }^{3}$.

Once the professional is able to evaluate and record the person's complaint, he/she can improve the care of the patient with pain ${ }^{4}$. But in the professional practice, the nursing team may face some difficulties in using pain as the fifth vital sign $n^{4.5}$. Given the above, the present study is justified by the need to know the difficulties encountered by these professionals in the assessment of pain as the fifth vital sign. Also, to present the mechanisms and actions adopted in the attempt to solve or reduce these difficulties to improve the management, the control, assessment, and care for patients who complain of pain. Thus, pain assessment is of great relevance to nurses as well as to other health professionals, and it is important that they have the knowledge and implement it in health institutions. The objective of this study was to identify and analyze, by an integrative review in the Brazilian and international literature, the difficulties faced by the nursing team to use pain as the fifth vital sign and the mechanisms and actions adopted.

\section{CONTENTS}

It is an integrative review of the literature, and the methodological reference was adopted to conduct this review ${ }^{6}$. This framework addresses six phases to be followed: elaboration of the guiding question, search or sampling in the literature, data collection, analysis of the studies included, discussion of the results and submission of the integrative review.

The guiding question of this survey was: what are the difficulties faced by the nursing team to use pain as the fifth vital sign? The search for scientific articles was carried out in the following databases: LILACS, BDENF (Nursing Database), Scielo, Pubmed, Scopus and Web of Science.

The Health Sciences Descriptors (DeCS) were used to locate the articles that composed the sample: nursing, pain, pain management, and vital signs in Portuguese, Spanish and English; and the MESH Database descriptors: nursing, pain, pain management, and vital signs. The Boolean operator represented by the connector term AND was used, and associations between all the selected descriptors.

As the selection criteria, the cut-off period from 1995 to 2017 was defined. Articles in Portuguese, Spanish, and English in the searched databases that answered the proposed question were selected. Publications in duplicate in the databases were excluded.

An integrative review data collection instrument was used that included variables such as study identification data (article title, periodical, authors, year, country of publication and language) and study characterization (objectives, type of study, subjects of the study, results, and conclusions) ${ }^{7}$.

The database search found 65,203 articles. There were 21 eligible articles in LILACS, 15 in Scielo, 13 in BDENF, seven in Pubmed, 14 in Scopus and 16 in Web of Science, totaling 86 eligible articles. Nine articles were in duplicate in LILACS, 15 in Scielo, 13 in BDENF, three in Scopus and eight in Web of Science, totaling 48 duplicate articles. Of these, 29 articles were excluded post-duplication and reading in full. Thus, in the critical and analytical reading, nine articles were selected, five from LILACS, one from Pubmed, and three from Scopus (Figure 1). Table 1 shows the synthesis of the results obtained from the selected articles regarding the variables of the title of the article, periodical, authors, year and country of publication and language

Of the articles selected, only one has been published in the last five years; five articles in the last 10 years and three articles published more than 10 years ago. Most were published in Brazil (five articles), the Portuguese language predominated (five articles), and four were described in English (Table 1). Regarding the type of study, the predominance was quantitative research (five articles), but it is worth mentioning the development of qualitative, mixed, and theoretical reflection studies. Of the subjects evaluated in the selected studies, the nurses prevailed, but there was also the participation of nursing technicians/assistants and patients. Regarding the level of evidence of the investigations analyzed in this review, eight studies are classified as evidence level VI and one with no level, indicating studies with low evidence levels.

Two categories were listed after analyzing the results and conclusions of the articles selected: 1) difficulties faced by the nursing team to use pain as the fifth vital sign; and 2) mechanisms and actions adopted to minimize the difficulties faced by nursing in using pain as the fifth vital sign.

Difficulties faced by nursing to use pain as the fifth vital sign The most reported difficulty in the articles included in this review was the lack of knowledge of the nursing team professionals. Some authors have mentioned that nurses have little knowledge of acute pain. Many said that they had a superficial knowledge in school and others report that they have never had access to this information, being something new ${ }^{15}$.



Figure 1. Flowchart of articles identification and selection Source: Prepared by the authors. 
Table 1. Characteristics of the articles included

\begin{tabular}{|c|c|c|c|c|c|}
\hline Authors & Title of the article & Periodical & Year & Country of publication & Language \\
\hline $\begin{array}{l}\text { Niekerk and } \\
\text { Martin }^{8}\end{array}$ & $\begin{array}{l}\text { The impact of the nurse-physician relationship on bar- } \\
\text { riers encountered by nurses during pain management }\end{array}$ & $\begin{array}{l}\text { Pain Management } \\
\text { Nursing }\end{array}$ & 2003 & Australia & English \\
\hline $\begin{array}{l}\text { Vallerand, Templin } \\
\text { and Hasenau }\end{array}$ & Barriers to pain management by home care nurses & $\begin{array}{l}\text { Home Health Care } \\
\text { Nurse }\end{array}$ & 2004 & United States & English \\
\hline $\begin{array}{l}\text { Pedroso and } \\
\text { Celich }\end{array}$ & $\begin{array}{l}\text { Pain: fifth vital sign, a challenge for the care in nu- } \\
\text { rsing }\end{array}$ & $\begin{array}{l}\text { Texto \& Contexto } \\
\text { Enfermagem }\end{array}$ & 2006 & Brazil & Portuguese \\
\hline $\begin{array}{l}\text { Blondal and } \\
\text { Halldorsdottir }\end{array}$ & $\begin{array}{l}\text { The challenge of caring for patients in pain: from the } \\
\text { nurse's perspective }\end{array}$ & $\begin{array}{l}\text { Journal of Clinical } \\
\text { Nursing }\end{array}$ & 2009 & United States & English \\
\hline Saça et al. ${ }^{3}$ & $\begin{array}{l}\text { Pain as } 5^{\text {th }} \text { vital sign: role of the nursing staff in the } \\
\text { private hospital with management of Basic Health } \\
\text { Unit }\end{array}$ & $\begin{array}{l}\text { Journal of the } \\
\text { Health Sciences } \\
\text { Institute }\end{array}$ & 2010 & Brazil & Portuguese \\
\hline $\begin{array}{l}\text { Bottega and } \\
\text { Fontana }^{12}\end{array}$ & $\begin{array}{l}\text { Pain as the fifth vital sign: use of the assessment sca- } \\
\text { le by nurses in general hospital }\end{array}$ & $\begin{array}{l}\text { Texto \& Contexto } \\
\text { Enfermagem }\end{array}$ & 2010 & Brazil & Portuguese \\
\hline Wang and Tsai ${ }^{13}$ & $\begin{array}{l}\text { Nurses' knowledge and barriers regarding pain ma- } \\
\text { nagement in intensive care units }\end{array}$ & $\begin{array}{l}\text { Journal of Clinical } \\
\text { Nursing }\end{array}$ & 2010 & United States & English \\
\hline $\begin{array}{l}\text { Nascimento and } \\
\text { Kreling }^{5}\end{array}$ & $\begin{array}{l}\text { Assessment of pain as the fifth vital sign: opinion of } \\
\text { nurses }\end{array}$ & $\begin{array}{l}\text { Acta Paulista de } \\
\text { Enfermagem }\end{array}$ & 2011 & Brazil & Portuguese \\
\hline $\begin{array}{l}\text { Araujo and } \\
\text { Romero }^{14}\end{array}$ & $\begin{array}{l}\text { Pain: evaluation of the fifth vital sign. A theoretical } \\
\text { reflection }\end{array}$ & $\begin{array}{l}\text { Brazilian Journal } \\
\text { of Pain }\end{array}$ & 2015 & Brazil & Portuguese \\
\hline
\end{tabular}

Source: Prepared by the authors.

Another difficulty mentioned in the articles was communication among professionals. In this respect, it should be noted that in some situations, the preference of health professionals for an autonomous practice may lead to a lack of communication with nurses, thus disregarding their opinions or decisions ${ }^{16,17}$.

Communication, many times complex and ineffective between the nurse and the physician, is associated with patients undesired outcomes, specifically prolonged hospital stay and injuries resulting from delays and errors in treatment ${ }^{18,19}$.

The work overload of the nursing professionals was also a difficulty mentioned in the studied material. It should be emphasized that the nurse task is not only to assist the patient. It also includes the training and qualification of nursing professionals, the management of materials and supplies, to interface with other health and administration professionals, provide information to patients and family members, therefore promoting a multiprofessional management for the benefit of the patient ${ }^{20}$. Very often, these professionals have more than one job with a high turnover in the workplace due to the low remuneration and the high level of stress ${ }^{21}$.

Another difficulty found in the present review was to understand the patient's pain. Health professionals, including the nursing staff, may, in some situations, undervalue the patients' pain reports, thereby stimulating them to tolerate a little more pain. There is a lack of openness in listening to them and these factors interfere in the measurement and assessment of pain ${ }^{4,22}$. Considering that pain is a unique, subjective and individual experience, it is up to the healthcare team to respect this condition, to interpret and intervene accordingly ${ }^{12}$. Other complicating factors found in the articles included in this study were the lack of understanding of the intensity scale by patients and professionals, and many times, the profession- al believes that the patients overestimate their pain and have difficulty to express it. Professionals also find it difficult to use evaluation scales, either due to lack of knowledge or difficulty in interpreting the pain measurement instruments ${ }^{5,23,24}$. It was also noted that many patients are reluctant to talk about pain because they fear being classified as frail and grouch ${ }^{25}$.

In the context about the use of instruments to assess pain, other difficulties stood out as the lack of these instruments and the absence of notes and interventions of the nursing staff. As a result, knowledge deficits and the lack of pain measurement instruments are barriers for these professionals to provide effective care with quality to patients. Some professionals are unaware of the instruments to measure pain and, therefore, they rely on common sense, religious beliefs, and practices experienced by other professionals in the management of pain ${ }^{15,26}$.

The absence of nursing notes related to the patient's pain may compromise the assistance. Therefore, improving the records is a goal to be achieved. These notes are also considered a way of communication between the teams and the different shifts, enabling better assistance ${ }^{27}$.

Other difficulties found in the articles include the lack of time to assess pain, failure to remember to assess pain, their saying that pain cannot be measured, not considering pain as a vital sign, and inadequate pain assessment. The lack of time of these professionals, especially of the nursing team that performs several activities during the work shift, the lack of knowledge of pain measurement techniques, and the language used when questioning pain, which may be difficult to understand by the patient, are also factors that contribute to an inadequate assessment ${ }^{28}$.

According to a study, the results showed that the nurses of the studied hospital had incipient knowledge about the ways 
to assess pain and did not consider pain as the fifth vital sign since their practice did not include its systematic assessment ${ }^{15}$. Continuing with the other difficulties found in the present review, we noticed that nursing staff often provides pain management care in a limited way, not mastering the mechanism of the painful picture. Handling pain in a limited way may lead to inadequate management of the pain symptom and may cause harm to the patient. Frequently, nursing professionals rely on verbal and non-verbal reports to identify patients' pain ${ }^{14}$.

\section{Mechanisms and actions adopted to minimize the diffi- culties faced by the nursing staff to use pain as the fifth vital sign}

The most cited mechanism/action was to establish educational processes with continuous pain management courses, and, sometimes, in a state of emergency. The literature shows the need to train nurses and the entire nursing team about several topics related to professional practice. Thus, to promote education in favor of care ensuring the development of differentiated and more qualified assistance. Education is the base that may encourage the nurse to adopt approaches that are beneficial to his/her own knowledge and to the patient who is being assisted ${ }^{29}$.

Another mechanism/action found in the articles is the reorganization of the curriculum of the graduate program, including pain and subjects alike. It should be noted that some undergraduate courses are not properly preparing future nurses for pain management, that is, the subject is superficially addressed in the academic environment. Thus, it is necessary to mobilize efforts to prepare future nursing professionals with a focus on pain as the fifth vital sign, connecting the holistic care to the development of technical and behavioral skills that recognize teamwork and interdisciplinarity ${ }^{30}$.

Among other mechanisms/actions found in the articles, it is worth mentioning the understanding about the importance of the working relationship among health professionals, which can have a significant effect on the barriers to manage pain better. Therefore, it is necessary to improve education in communication in the undergraduate course to enrich their understanding of the role of each of them in front of the patient. In this way, it will be possible to broaden their skills to convey appropriate and important information about patient care with verbal and non-verbal communication ${ }^{31}$.

Other points mentioned refer to realizing the importance of the multidimensional knowledge on pain management, and a more holistic approach to care. The nurse and all healthcare professionals play a fundamental role in the control of pain performing a diagnostic evaluation, intervention, monitoring of the results of the treatment and communicating the information about pain. Therefore, the theoretical and practical knowledge should be associated with the purpose of providing more qualified care to the patient with pain, that is providing humanized care ${ }^{10.15}$.

Some articles mentioned the nurses' participation in the implementation of pain as the fifth vital sign in their work environment as a mechanism/action to minimize these difficulties, in partnership with all health professionals and with the use of case studies. The professional should encourage the team to rethink their roles and attributions, based on the reference of care with the purpose of achieving efficiency in the nursing work ${ }^{32}$. The nurse should also guide, perform and encourage the team about the need to carry out case studies, to evaluate the issue of pain in their professional practice so that the results of these studies are used as parameters that can be adopted in the assistance provided $^{33}$.

Finally, the mechanism/action regarding the use of scales is of great relevance for the clinical practice. It should be emphasized, therefore, that medical and nursing educational institutions should offer disciplines or courses with the objective of teaching and disseminating the use of instruments and/or scales to measure and assess pain with a humanistic perspective $^{10}$.

\section{CONCLUSION}

There are few studies in this subject, and many nurses have difficulties in using pain as the fifth vital sign, but some mechanisms/ actions can be adopted by all health professionals to minimize these difficulties.

Due to the difficulties presented in this study about the use of pain as the fifth sign, it is recommended to establish a continuous education program for health professionals in the workplace. Other actions recommended are to conduct more research, to restructure the undergraduate program curriculum to include the subject of pain, and the use of a more holistic perspective in care, as well as the use of scales in the clinical practice.

There is also the need to raise the awareness of the nursing team and all health professionals about the importance of their commitment. Together with the multidisciplinary team, they can be successful in controlling and managing the patient's pain, addressing it as the fifth vital sign, provide a humanized care that may influence the improvement of patients' health and quality of life.

\section{REFERENCES}

1. Purser L, Warfield K, Richardson C. Making pain visible: an audit and review of documentation to improve the use of pain assessment by implementing pain as the fifth vital sign. Pain Manag Nurs. 2014;15(1):137-42.

2. Campbell JN. The fifth vital sign revisited. Pain. 2016;157(1):3-4.

3. Saça CS, Carmo, FA, Arbuleia JP, Souza RC, Alves SA, Rosa BA. A dor como $5^{\circ}$ sinal vital: atuaçấo da equipe de enfermagem no hospital privado como gestấo do Sistema único de Saúde (SUS). J Health Sci Inst. 2010;28(1):35-41.

4. Nogueira MF. Dor: identificando os métodos de avaliação e descrevendo o cuidado de enfermagem. Rev Enferm UFPE. 2012;6(1):1556-65.

5. Nascimento LA, Kreling, MC. Avaliação da dor como quinto sinal: opiniāo de profissionais de enfermagem. Acta Paul Enferm. 2011;24(1):50-4.

6. Souza MT, Silva MD, Carvalho R. Revisão integrativa: o que é e como fazer. Einstein. 2010;8(1):102-6.

7. Fernandes DL. Representaçốes sociais de adolescentes sobre o câncer de colo do útero [dissertação]. Recife: Universidade Federal do Pernambuco; 2011.

8. Niekerk LM, Martin F. The impact of the nurse-physician relationship on barriers encountered by nurses during pain management. Pain Manag Nurs. 2003;4(1):3-10.

9. Vallerand $\mathrm{AH}$, Templin T, Hasenau SM. Barriers to pain management by home care nurses. Home Health Nurse. 2004;22(12):831-40. 
10. Pedroso RA, Celich KL. Dor: Quinto sinal vital, um desafio para o cuidar em Enfermagem. Rev Texto Contexto Enferm. 2006;15(2):270-6.

11. Blondal K, Halldorsdottir $S$. The challenge of caring for patients in pain: from the nurse's. J Clin Nurs. 2009;18(20):2897-906.

12. Bottega FH, Fontana RT. A dor como quinto sinal vital: Utilização da escala de avaliação por enfermeiros de um Hospital geral. Rev Texto Contexto Enferm. 2010;19(2):283-90.

13. Wang HL, Tsai YF. Nurses' knowledge and barriers regarding pain management in intensive care units. J Clin Nurs. 2010;19(21):3188-96.

14. Araujo LC, Romero B. Dor: Avaliação do $5^{\circ}$ sinal vital. Uma reflexấo teórica. Rev Dor. 2015;16(4):291-6.

15. Queiróz DT, Carvalho MA, Carvalho GD, Santos SR, Moreira AS, Silveira MF. Dor - 5o sinal vital: conhecimento de enfermeiros. Rev Enferm UFPE. 2015;9(4):7186-92.

16. Aston J, Shi E, Bullôt H, Galway R, Crisp J. Qualitative evaluation of regular morning meetings aimed at improving interdisciplinary communication and patient outcomes. Int J Nurs Pract. 2015;11(5):206-13.

17. Vaismoradi M, Salsali M, Esmaeilpour M, Cheraghi MA. Perspectives and experiences of Iranian nurses regarding nurse-physician communication: a content analysis study. Jpn J Nurs Sci. 2011;8(2):184-9.

18. Ellison D. Communication skills. Nurs Clin North Am. 2015;50(1):45-57.

19. O'Daniel M, Rosenstein AH. Professional Communication and Team Collaboration. In: Hughes RG (Ed.). Patient safety and quality: an evidence-based handbook for nurses. Rockville: Agency for Healthcare Research and Quality; 2008. 1403p.

20. Novaretti MC, Santos EV, Quitério LM, Gallotti-Daud RM. Sobrecarga de trabalho da enfermagem e incidentes e eventos adversos em pacientes internados em UTI. Rev Bras Enferm. 2014;67(5):692-9.

21. Van PB, Timmermans O, Weeks SM, Van HD, Wouters K, Franck E. Nursing unit teams' matter: impact of unit-level nurse practice environment, nurse work characteristics, and burnout on nurse reported job outcomes, and quality of care, and patient adverse events-a cross-sectional survey. Int J Nurs Stud. 2014;51(8):1123-34.
22. Andrade FA, Pereira, LV, Sousa FA. [Pain measurement in the elderly: a review]. Rev Lat Am Enfermagem. 2006;14(2):271-6. Portuguese.

23. Rampanjato RM, Florence M, Patrick NC, Finucane BT. Factors influencing pain management by nurses in emergency departments in Central Africa. Emerg Med J. 2006;24(7):475-6

24. Ribeiro NC, Barreto SC, Hora EC, Sousa, RM. O enfermeiro no cuidado à vítima de trauma com dor: o quinto sinal vital. Rev Esc Enferm USP. 2011;45(1):146-52.

25. Pessini L. Humanização da dor e sofrimento humanos no contexto hospitalar. Rev Bioética. 2002;10(2):51-72

26. Linhares MB, Fernanda NP. Dor em neonatos e crianças: avaliaçấo e intervençóes năo farmacológicas. Temas Psicol. 2010;18(2):307-25.

27. Rigotti MA, Ferreira AM. Intervençôes de enfermagem ao paciente com dor. Arq Ciênc Saúde. 2005;12(1):50-4.

28. Kazanowski MK, Laccetti MS. Dor: Fundamentos, abordagem clínica, tratamento. Rio de Janeiro: Guanabara Koogan; 2005. 165p.

29. Andrade KC, Aires RD, Kangussu LM. Atuaçáo do enfermeiro na avaliaçáo da dor e na administração de fármacos opióides: Uma revisão bibliográfica. Revista NBC. 2015;5(9):1-10

30. Romanek FA, Avelar MC. Percepção dos docentes acerca do ensino da dor para graduandos em enfermagem. Rev Eletr Enf. 2013;15(2):463-70.

31. Bandboni M, Vaismoradi M, Salsali M, Snelgrove S. Iranian physicians' perspectives regarding nurse-physician professional communication: Implications for nurses. Res Theory Nurs Pract. 2017;31(3):202-18.

32. Bernardes A, Ramos BM, Betela-Junior J, Paiva PN. Supervisão do enfermeiro no atendimento pré-hospitalar móvel: visão dos auxiliares de enfermagem. Ciênc Cuid Saude. 2009;8(1):79-85.

33. Pagani R, Andrade LO. Preceptoria de Território, Novas práticas e saberes na Estratégia de Educação Permanente em Saúde da Família: o estudo do caso de Sobral, CE. Saúde Soc. 2012;21(1):94-106. 